\title{
Extracellular ATP in the lymphohematopoietic system: P2Z purinoceptors and membrane permeabilization
}

P.M. Persechini, R.C. Bisaggio,

J.L. Alves-Neto and

R. Coutinho-Silva
Laboratório de Imunobiofísica, Instituto de Biofísica Carlos Chagas Filho, Universidade Federal do Rio de Janeiro, Rio de Janeiro, RJ, Brasil
Correspondence

P.M. Persechini

Instituto de Biofísica, UFRJ

Bloco G, CCS

21949-900 Rio de Janeiro, RJ

Brasil

Fax: 55 (021) 280-8193

E-mail: pedro@chagas.biof.ufrj.br

Presented at the International Meeting on Cytokines, Angra dos Reis, RJ, Brasil, November 24-28, 1996.

Research supported by FINEP, CNPq, FAPERJ, PRONEX and Fundação Universitária Jose Bonifácio (FUJB). $\ldots \ldots \ldots \ldots \ldots \ldots$.

Received September 4, 1997 Accepted September 22, 1997 ..................

\section{Abstract}

The effects of extracellular nucleosides and nucleotides on many organs and systems have been recognized for almost 50 years. The effects of extracellular ATP $\left(\mathrm{ATP}_{\mathrm{o}}\right), \mathrm{UTP}_{\mathrm{o}}, \mathrm{ADP}_{\mathrm{o}}$, and other agonists are mediated by $\mathrm{P} 2$ purinoceptors. One of the most dramatic effects of $\mathrm{ATP}_{\mathrm{o}}$ is the permeabilization of plasma membranes to low molecular mass solutes of up to $900 \mathrm{Da}$. This effect is evident in several cells of the lymphohematopoietic system and is supposed to be mediated by $\mathrm{P} 2 \mathrm{Z}$, an ATP ${ }^{4-}$-activated purinoceptor. Here, we review some basic information concerning P2 purinoceptors and focus our attention on P2Z-associated phenomena displayed by macrophages. Using fluorescent dye uptake, measurement of free intracellular $\mathrm{Ca}^{2+}$ concentration and electrophysiological recordings, we elucidate some of the events that follow the application of ATP to the extracellular surface of macrophages. We propose a regulatory mechanism for the P2Zassociated permeabilization pore. The presence of $\mathrm{P} 2$ purinoceptors in cells of the lymphohematopoietic system makes them potential candidates to mediate immunoregulatory events.

\section{Effects of extracellular ATP}

The effects of extracellular nucleosides and nucleotides on many organs and systems have been recognized for almost 50 years (1$3)$. Early investigators concentrated on the actions of extracellular ATP $\left(\mathrm{ATP}_{\mathrm{o}}\right)$ and adenosine on the cardiovascular system, including their shock-inducing properties and their applications to geriatric patients with cardiovascular disorders.

In non-lymphoid tissues, both norepinephrine and acetylcholine can be found colocalized with $\mathrm{ATP}_{0}$. Actually, in the nervous system, ATP is stored and released with norepinephrine and acetylcholine, and can act either as a neurotransmitter or as a co-transmitter (1-3). In the endocrine system, $\mathrm{ATP}_{\mathrm{o}}$ can act as a secretagogue for hormones, as demonstrated in the pancreas and adrenals.

In the lymphohematopoietic system, one of the most dramatic effects of $\mathrm{ATP}_{\mathrm{o}}$ is the permeabilization of plasma membranes of several cell types to low molecular mass solutes of up to $900 \mathrm{Da}$. This phenomenon requires $\mathrm{mM}$ concentrations of $\mathrm{ATP}_{\mathrm{o}}$ and has already been described in macrophages, mast cells, phagocytic cells of the thymic reticulum, bone marrow cells, and thymic as 
well as peripheral blood lymphocytes (3-9). At lower doses, however, $\mathrm{ATP}_{\mathrm{o}}$ has been associated with many different phenomena. In thymocytes, $\mathrm{ATP}_{\mathrm{o}}$ can modulate DNA synthesis, blastogenesis, and apoptosis $(3,10)$ and in the monocytic lineage it can stimulate the synthesis of prostaglandin and leukotriene C4, induce the maturation of IL- $1 \beta$, increase the mRNA levels of nitric oxide synthase, and induce the production of reactive oxygen radicals (11-15). These data, which clearly indicate the importance of nucleotides and nucleosides as intercellular mediators, stimulated us to investigate their role as immune regulators. In the following sections we will review some of the basic properties of the P2 purinoceptors and then we will focus our attention on the $\mathrm{P} 2 \mathrm{Z}$ purinoceptors associated with the phenomenon of macrophage permeabilization.

\section{P2 purinoceptors}

Purinoceptors mediate most of the effects of extracellular nucleotides and nucleosides. Two classes of purinoceptors, with several subtypes, have been proposed based on pharmacological, biochemical and functional data (1). P1 purinoceptors were subdivided according to the relative potencies of a series of adenine analogues and their effects on the levels of adenylate cyclase activity; P2 purinoceptors have been originally postulated on the basis of relative potencies of ATP, ADP and analogues, as well as on the basis of selective antagonisms. Based on these criteria, at least $4 \mathrm{P} 1$ and $6 \mathrm{P} 2$ subtypes of purinoceptors have been identified $(1,3,16)$. P2Y and $\mathrm{P} 2 \mathrm{U}$ purinoceptors act via the intracellular $\mathrm{G}$ protein cascade. $\mathrm{P} 2 \mathrm{U}$ purinoceptors have a stronger specificity for UTP over ATP. P2T, $\mathrm{P} 2 \mathrm{X}$, and $\mathrm{P} 2 \mathrm{Z}$ purinoceptors appear to act as ligand-gated channels. All P2 purinoceptors induce the increase of free intracellular $\mathrm{Ca}^{2+}$ concentration. Detailed pharmacological and molecular studies of $\mathrm{P} 2$ purinoceptors have been delayed by the lack of specific agonists and antagonists.
Several P2 purinoceptors have been recently cloned, leading to a new proposal for their classification based mainly on their homology and signal transduction mechanism (16). $\mathrm{P} 2 \mathrm{X}$ purinoceptors $\left(\mathrm{P}^{2} \mathrm{X}_{1}-\mathrm{P} 2 \mathrm{X}_{7}\right)$ are ligand-gated ion channels that are permeable to $\mathrm{Na}^{+}, \mathrm{K}^{+}$and, exceptionally, to $\mathrm{Ca}^{2+}$, while $\mathrm{P} 2 \mathrm{Y}$ purinoceptors $\left(\mathrm{P}_{2} \mathrm{Y}_{1}-\mathrm{P} 2 \mathrm{Y}_{6}\right.$ ) are $\mathrm{G}$ protein-coupled, leading in some cases to the mobilization of intracellular $\mathrm{Ca}^{2+}$. Unfortunately, a clear association between the gene product and the physiologically expressed receptors has not yet been established for all cloned molecules.

Some of the $\mathrm{P} 2$ purinoceptors have been characterized in cells of the lymphohematopoietic system and other cells and tissues of interest to the immunologist (3). In macrophages, there have been reports of the expression of $\mathrm{P} 2 \mathrm{Z}, \mathrm{P} 2 \mathrm{Y}$, and $\mathrm{P} 2 \mathrm{U}$ purinoceptors $(3,17-19)$.

P2Z purinoceptors in the lymphohematopoietic system

P2Z purinoceptors are expressed in several cells of the lymphohematopoietic system, including macrophages, microglial cells, mast cells, neutrophils, megakaryocytes, multipotent hematopoietic stem cells, thymocytes, and some peripheral lymphocyte subsets $(1,3,7)$. This receptor has also been described in some transformed cell lines and in rat parotid acinar cells $(3,20)$. The effects of $\mathrm{ATP}_{\mathrm{o}}$ are mediated by $\mathrm{ATP}^{4-}$ ions and ATP- $\gamma$-S, but not by ADP, AMP, or adenosine $(1,3)$. Addition of $\mathrm{Mg}^{2+}$ inhibits the P2Z-mediated phenomenon, supposedly due to the lack of agonist action of Mg-ATP2molecules.

The presence of $\mathrm{P} 2 \mathrm{Z}$ purinoceptors can be ascertained by the activation of cation selective conductance and $\mathrm{Ca}^{2+}$ mobilization, together with their most striking characteristic, i.e., the permeabilization of cell membranes to low molecular mass solutes with $\mathrm{M}_{\mathrm{r}}$ of up to $900(3,4)$. In peripheral blood lymphocytes, thymocytes and hematopoietic stem 
cells, permeabilization seems to be limited to molecules of $M_{r}$ below 400 (3). This difference in molecular mass cut-off may reflect the existence of subtypes of the P2Z purinoceptors or a differential modulation of membrane permeability according to the cell type.

Important differences can be observed among the several manifestations of P2Z activation. Cation currents and an increase of free intracellular $\mathrm{Ca}^{2+}$ concentration can be detected a few milliseconds after stimulation and can be triggered at $\mu \mathrm{M}$ concentrations of $\mathrm{ATP}_{\mathrm{o}}$. On the other hand, membrane permeabilization is a much slower phenomenon that will only become evident several seconds or even minutes after stimulation and requires $\mathrm{mM}$ concentrations of $\mathrm{ATP}_{\mathrm{o}}$, with a maximum at $5-10 \mathrm{mM}$.

The molecular nature of $\mathrm{P} 2 \mathrm{Z}$ purinoceptors is not fully understood and evidence exists indicating that fast-activating transmembrane cation currents and membrane permeabilization (pore formation) are indeed separate phenomena $(21,22)$. The $\mathrm{P} 2 \mathrm{X}_{7}$ molecule shares several pharmacological and electrophysiological properties with $\mathrm{P} 2 \mathrm{Z}$ purinoceptors such as the activation by $\mathrm{ATP}^{4-}$ and BzATP, and the induction of fast-activating cation current, leading some groups to name this molecules $\mathrm{P} 2 \mathrm{Z} / \mathrm{P} 2 \mathrm{X}_{7}$.

The physiological function of $\mathrm{P} 2 \mathrm{Z}$ purinoceptors is still an open question and due to the lack of more specific pharmacological tools, the data available should be considered with caution. A role in cell death has been proposed based mainly on the permeabilization phenomenon and on the induction of apoptosis in some cell types such as thymocytes and macrophages (23). In macrophages, $\mathrm{P} 2 \mathrm{Z}$ activation has been associated with IL-1 maturation and release (24), formation of multinucleated giant cells (19), and the elimination of macrophages infected by intracellular parasites (25). In human lymphocytes, P2Z purinoceptors have been associated with the loss of L-selectin (26).
Permeabilization of macrophages, monocytes and $\mathrm{T}$ cells by ATP

The P2Z-associated permeabilization phenomenon can be easily observed by the uptake of fluorescent dyes such as the cytoplasm space marker Lucifer yellow, and the DNA markers ethidium bromide, propidium iodine and TO-PRO-3. Figure 1 illustrates flow cytometry analysis of thioglycollateelicited murine intraperitoneal cells and fresh human peripheral blood mononuclear cells (PBMCs) permeabilized for $10 \mathrm{~min}$ in the presence of high extracellular ATP concentration (Alves-Neto JL, Coutinho-Silva R and Persechini PM, unpublished data). Murine cells, mostly macrophages, were readily permeabilized (Figure 1A) while PBMCs displayed a more complex pattern of permeabilization (Figure 1B). Three-color analysis of the PBMCs showed that monocytes (CD14 ${ }^{+}$ cells) had a strong permeabilization pattern, reaching an intracellular fluorescence intensity 10 -fold higher than that obtained in the absence of ATP (Figure 1C). On the other hand, $\mathrm{T}$ cells $\left(\mathrm{CD}^{+}\right)$displayed a fluorescence increase of only 3-5-fold (Figure 1D). The analysis of other cell populations present in PBMCs is currently under way. The conclusion that the above-described permeabilization is a P2Z-associated phenomenon comes from additional experiments showing that it is not induced by extracellular UTP and that it can be blocked by high $(5-10 \mathrm{mM})$ extracellular $\mathrm{Mg}^{2+}$ concentration (Alves-Neto JL, Coutinho-Silva R and Persechini PM, unpublished data).

Changes in intracellular $\mathrm{Ca}^{2+}$ concentration induced by ATP $_{\mathrm{o}}$ and $U T P_{O}$ and other signal

transduction pathways

The pattern of the increase of intracellular $\mathrm{Ca}^{2+}$ concentration induced by the interaction of a P2 purinoceptor agonist may 

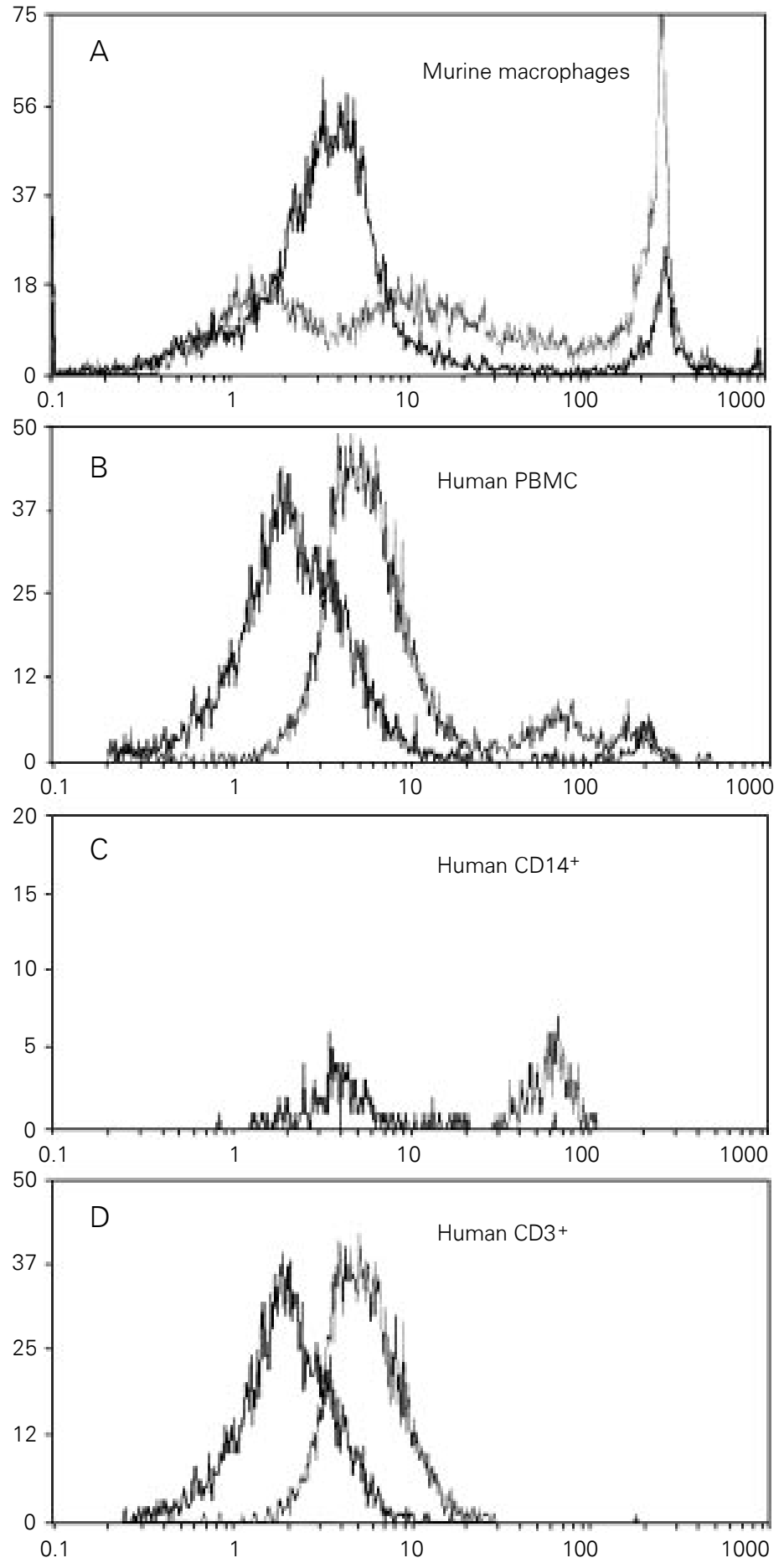

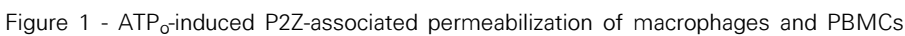
Flow cytometry analysis was performed on freshly isolated thioglycollate-elicited murine intraperitoneal cells (A) and human PBMCs (B-D). Murine cells were not stained with antibodies, while PBMCs were stained with FITC-labeled anti-CD3 and PE-labeled antiCD14 immediately before the experiment. The permeabilization assay was performed by exposing cells to either $0 \mathrm{mM}$ (darker line) or $10 \mathrm{mM}$ (lighter line) of extracellular ATP for 10 min at $37^{\circ} \mathrm{C}$ in the presence of a fluorescent dye (ethidium bromide in $\mathrm{A}$ and TO-PRO-3 in $\mathrm{B}$ D). Experiments were performed using a COULTER Epics-Elite flow cytometer and double excitation wavelengths: $633 \mathrm{~nm}$ for TO-PRO-3 and $488 \mathrm{~nm}$ for all other fluorochromes. differ according to the subtype of receptors expressed by the cell and the experimental conditions. Therefore, a deeper insight into the nature of the $\mathrm{ATP}_{\mathrm{o}}$-induced permeabilization phenomenon can be obtained by studying cells loaded with fluorescent $\mathrm{Ca}^{2+}$ indicators. Figure 2 shows a representative experiment performed with adherent murine macrophages. The addition of $\mathrm{ATP}_{\mathrm{o}}$ at $37^{\circ} \mathrm{C}$ induced a fast-activating spike of $\mathrm{Ca}^{2+}$ followed by a slowly activating increase in intracellular $\mathrm{Ca}^{2+}$ concentration (Figure $2 \mathrm{~A}$ ). The concentration of $\mathrm{Ca}^{2+}$ may return to basal levels if $\mathrm{ATP}_{\mathrm{o}}$ is withdrawn (Figure 2A) but a 10-20-min exposure to the agonist will usually render the process irreversible, leading to a continuous rise in intracellular $\mathrm{Ca}^{2+}$ concentration. This result suggests that a continuous influx of $\mathrm{Ca}^{2+}$ takes place as the consequence of irreversible membrane permeabilization (Figure 2B). In agreement with this hypothesis, it can be demonstrated that the slowly activating increase in intracellular $\mathrm{Ca}^{2+}$ concentration is also temperature dependent, becoming almost completely inhibited at $25^{\circ} \mathrm{C}$ (Figure 2C). Moreover, the P2U agonist UTP, a nucleotide that does not induce membrane permeabilization, induced only a fast-activating $\mathrm{Ca}^{2+}$ spike both at 25 and $37^{\circ} \mathrm{C}$ (Figure 2D-E).

The change in free intracellular $\mathrm{Ca}^{2+}$ concentration is only a part of the complete cascade of the poorly characterized signal transduction pathways employed by all $\mathrm{P} 2$ purinoceptors. Macrophages have P2Z, P2Y, and P2U purinoceptors $(3,17,18)$ and, besides the receptor-gated cation channels such as the ones that will be described later in this review, candidate intermediates include $G$ protein, phospholipases $\mathrm{A}_{2}$ and $\mathrm{D}$, and calmodulin-regulated pathways $(3,22,27,28)$. $\mathrm{P} 2 \mathrm{Y}$ and $\mathrm{P} 2 \mathrm{U}$ purinoceptors may induce the release of intracellular $\mathrm{Ca}^{2+}$ stores, while P2Z has been shown to open G proteincoupled transmembrane $\mathrm{Ca}^{2+}$ channels (29) and to activate phospholipase D in macrophages (30) and lymphocytes (31). More- 
over, the $\mathrm{P} 2 \mathrm{Z}$-associated $\mathrm{P} 2 \mathrm{X}_{7}$ molecule has a cytoplasmic tail that is required to induce permeabilization but not a cation current, suggesting a role in an as yet unidentified transduction pathway (32).

Ion currents, small channels and pores induced by $\mathrm{ATP}_{\mathrm{o}}$ in macrophages

Some of the most powerful tools to study receptor pharmacology are provided by electrophysiological techniques. Plasma membranes of cells of the lymphohematopoietic system can be routinely patch-clamped, providing a high-resolution time-resolved description of many events that follow receptor-ligand interaction. Recently, a better understanding of the properties of the $\mathrm{P} 2 \mathrm{Z}$ purinoceptor has been achieved by applying these techniques to macrophages and other cells $(9,18,29,32-38)$.

Signal transduction mediated by all P2 purinoceptors involves the regulation of ion channels $(3,27)$. P2Z purinoceptors are associated with membrane depolarization and permeabilization or "pore" formation, two phenomena that should induce striking modifications in membrane conductance. Early studies using macrophages and mast cells $(33,39)$ demonstrated the existence of a nonselective cation conductance activated by $\mathrm{ATP}_{\mathrm{o}}{ }^{4-}$ that can induce membrane depolarization but a direct correlation between this depolarization with the phenomenon of membrane permeabilization to low molecular weight solutes has never been demonstrated. The results recently obtained in our laboratory have demonstrated the existence of a more complex pattern of transmembrane currents, allowing us to describe new unitary channels involved in these phenomena and to start to understand their regulatory mechanism $(9,18,36,38)$.

Figure 3 illustrates whole-cell currents and unitary channels obtained by applying $\mathrm{ATP}_{0}$ to macrophages patch-clamped under

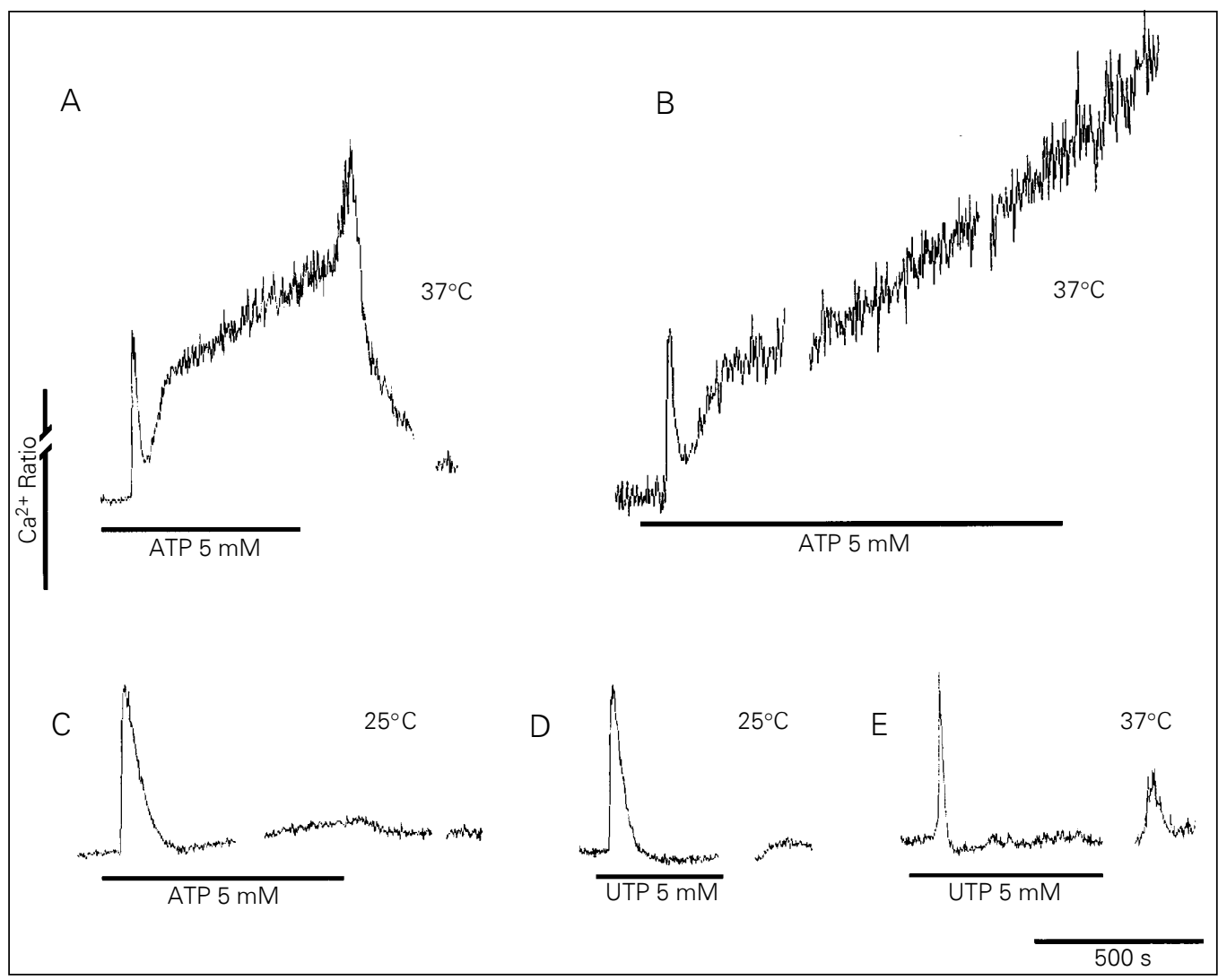

Figure 2 - ATP $_{0^{-}}$and UTP O-induced changes in intracellular $\mathrm{Ca}^{2+}$. Thioglycollate-elicited murine macrophages were cultivated on glass coverslips for a few days and labeled with the fluorescent intracellular $\mathrm{Ca}^{2+}$ indicator Fura-2 AM immediately before the experiment. Fluorescence measurements were made using a microscope equipped with a spectrofluorometer that permitted the measurement of fast-activating $\mathrm{Ca}^{2+}$ signals of a small number of cells $(30-50$ cells). An extracellular solution containing 0 or $5 \mathrm{mM}$ of either ATP (A-C) or UTP (D-E) was continuously perfused through the culture chamber maintaining the cells at the indicated temperature. The presence of the agonist is indicated by the horizontal bar in each record. The gaps in the records indicate irrelevant interruptions of the data storage system. 
Figure 3 - Currents and ion channels associated with $\mathrm{P} 2 \mathrm{Z}$ purinoceptors. Thioglycollate-elicited murine macrophages were placed in a heated culture chamber and patch-clamp records were obtained by a heat-polished micropipette filled with the desired solution. $A$, Whole-cell record of a macrophage; $B$, outside-out record of 8-pS single channels; $C$, cell-attached record of a pore of approximately 400 pS. In $A$ and $B$, ATP was applied iontophoretically by placing the tip of a second micropipette close to the surface of the patchclamped cell (horizontal bars on the left). In $C$, the P2Z agonist BzATP was continuously present in the extracellular medium. several experimental conditions. In the whole-cell configuration (Figure $3 \mathrm{~A}$ ), the application of ATP pulses close to the macrophage extracellular surface induces a biphasic transmembrane current that consists of a fast-activating inward (depolarizing) current, followed by a delayed outward (hyperpolarizing) current. Ion-exchange and other complementary experiments have dem- onstrated that the outward current can be ascribed to a $\mathrm{Ca}^{2+}$-dependent $\mathrm{K}^{+}$current, while the inward current is selective for small cations such as $\mathrm{Na}^{+}$and $\mathrm{K}^{+}(18,34,36)$. Therefore, the activation of macrophage $\mathrm{P} 2 \mathrm{Z}$ purinoceptors induces two opposite phenomena: a fast-activating cation current that can depolarize the macrophage membrane, and a delayed $\mathrm{K}^{+}$current that drives the membrane

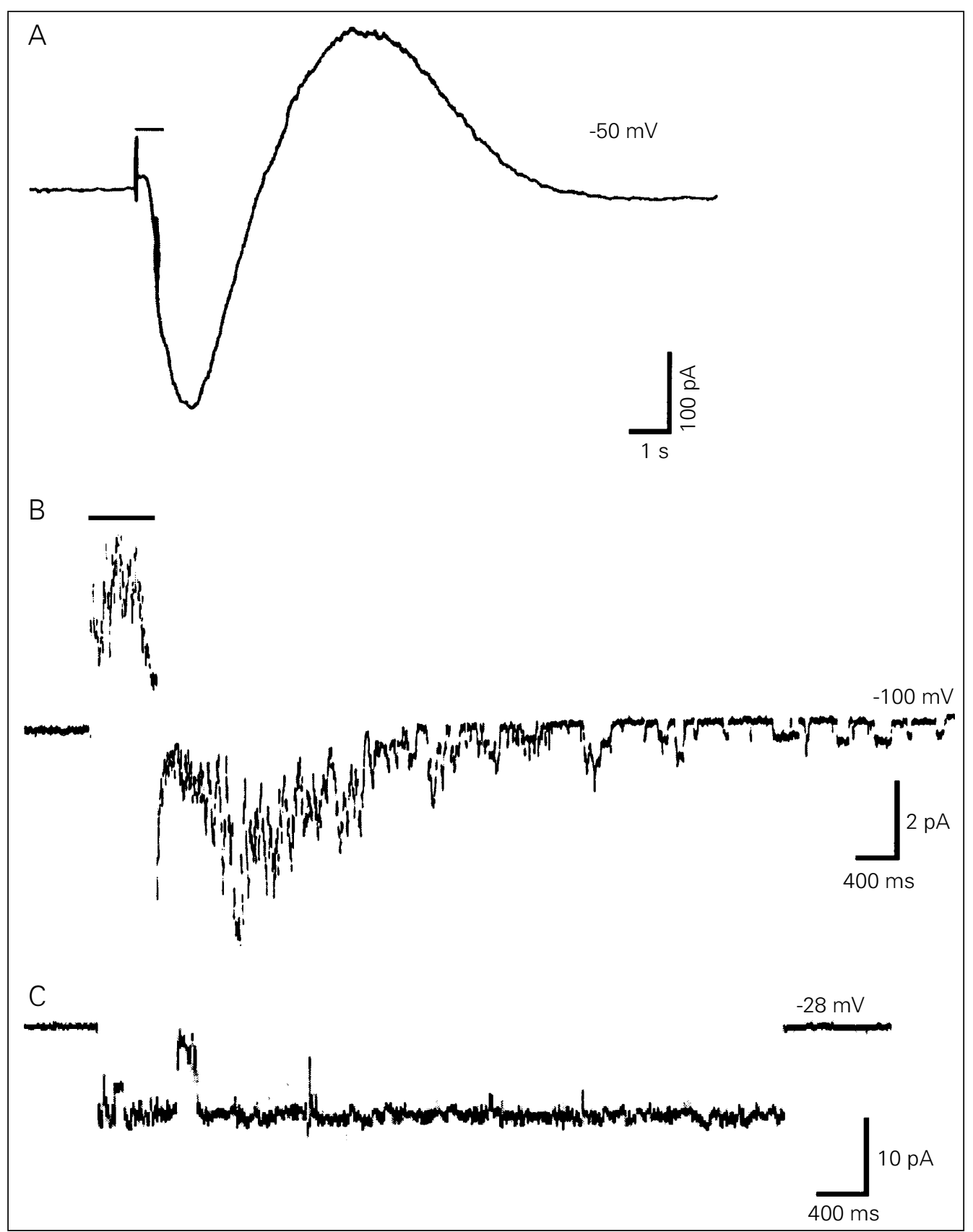


potential towards more negative values.

The fast-activating depolarizing current was resolved at the single channel level using the patch-clamp technique in the outside-out configuration (Figure 3B). This type of experiment allowed us to conclude that it is a ligand-gated ion channel with a unitary conductance in the range of 5-8 pS. This channel is too small and does not support the transport of larger molecules such as Tris and NMDG and, therefore, cannot be directly involved in the transport of molecules of molecular mass up to $900 \mathrm{Da}$.

The experiments described above have elucidated a part of the cascade of events associated with signal transduction by $\mathrm{P} 2 \mathrm{Z}$ purinoceptors. However, they have failed to describe currents and/or channels that could explain the permeabilization phenomenon. In order to solve this problem we performed patch-clamp experiments in the cell-attached configuration, a condition that allows the study of single channels without interfering with the intracellular milieu. A typical experiment is shown in Figure 3C. A few minutes after the application of ATP, a channel with a conductance of approximately $409 \mathrm{pS}$ starts to open (40). These channels are voltage dependent and display several properties of the P2Z-associated permeabilization phenomenon: they are permeable to both large cations and anions, such as Tris, NMDG, and glutamate; their opening is favored at temperatures higher than $30^{\circ} \mathrm{C}$; they are blocked by oxidized ATP and $\mathrm{Mg}^{2+}$; they can be triggered by BzATP, but not by UTP or ADP. We thus concluded that these pores are associated with the P2Z permeabilization phenomenon and we called them " $Z$ pores".

Experiments like the one shown in Figure $3 \mathrm{C}$ lead us to conclude that the opening of $Z$ pores is regulated by second messengers since the patch of membrane that contains the pore is inside the pipette and has no access to the applied ATP.
The P2Z-associated permeabilization phenomenon is not related to connexin-43

In a separate series of experiments we also investigated the possibility that connexin-43 hemichannels, macromolecular structures most frequently associated with direct cell-cell communication, could be involved in $\mathrm{ATP}_{\mathrm{o}}$-induced permeabilization phenomena, the hallmark characteristic of P2Z purinoceptors. This hypothesis was supported by data indicating that connexin- 43 mRNA is expressed in $\mathrm{ATP}_{\mathrm{o}}$-susceptible macrophages but not in $\mathrm{ATP}_{\mathrm{o}}$-resistant macrophages (41). We and our colleagues (37) have confirmed the presence of connexin-43 mRNA in P2Z-expressing peritoneal macrophages and J774 line; however, the ATPinduced permeabilization in macrophages was not affected either in the presence of octanol or at low $\mathrm{pH}$, two conditions expected to close gap-junction pores. Moreover, $\mathrm{ATP}_{\mathrm{o}}$-induced Lucifer yellow uptake was observed in peritoneal macrophages derived from connexin-43 knockout mice (37). These results clearly indicate that hemigap junctions are not functionally expressed to support $\mathrm{ATP}_{\mathrm{o}}$-induced permeabilization.

The regulation of the $\mathrm{P} 2 \mathrm{Z}$-associated ATP $_{\mathrm{o}}$-induced permeabilization: a hypothesis

The permeabilization of $\mathrm{P} 2 \mathrm{Z}$-expressing plasma membranes by $\mathrm{ATP}^{4-}$ is a potentially lethal phenomenon that must require strong regulatory mechanisms in order to avoid uncontrolled cell death. Figure 4 represents some of the events that are involved in the response of macrophages to $\mathrm{ATP}_{\mathrm{o}}$ and the proposed mechanism that may be important to regulate the permeabilization phenomenon. According to our results, the fast-activating depolarizing current ( $\mathrm{P} 2 \mathrm{X}_{7}$ channel), the delayed $\mathrm{Ca}^{2+}$-dependent $\mathrm{K}^{+}$hyperpolar- 
Figure 4 - Regulation of the P2Zassociated ATP $_{0}$-induced permeabilization: a hypothesis. In this simplified model, P2Z-associated phenomena are represented. For more details see the last section of the text. EB = Ethidium bromide; $L Y=$ Lucifer yellow.

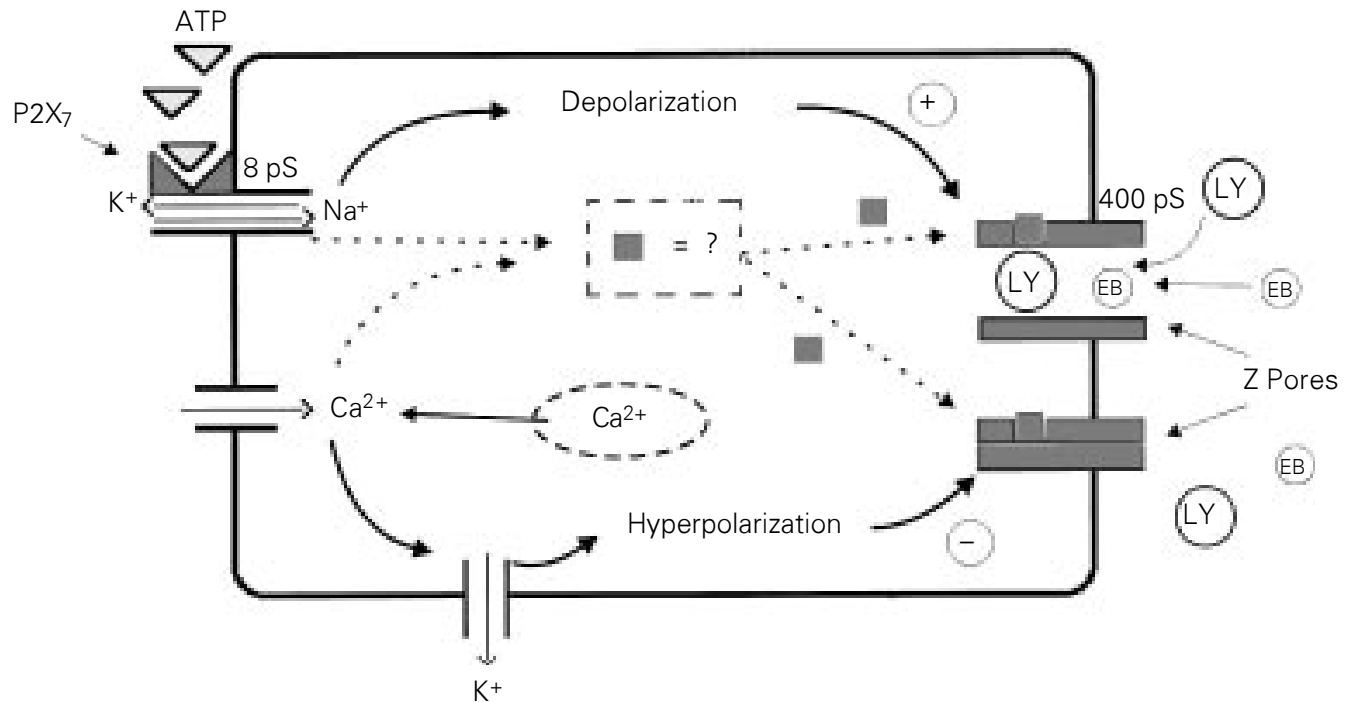

izing current and the permeabilization phenomenon (Z pores) are probably distinct phenomena. The opening of the voltage-dependent $\mathrm{Z}$ pores involves the mobilization of as yet unidentified second messengers and the depolarization induced by the ligand-gated cation channel $\mathrm{P} 2 \mathrm{X}_{7}$. In opposition to this mechanism, the simultaneous opening of $\mathrm{Ca}^{2+}$-dependent $\mathrm{K}^{+}$channels will move the membrane potential towards more negative values, forcing $\mathrm{Z}$ pores to shut down. Intracellular $\mathrm{Ca}^{2+}$ will initially increase due to at least two mechanisms: release from intracellular stores and opening of $\mathrm{Ca}^{2+}$ channels. $\mathrm{P} 2 \mathrm{Z}$ (shown as $\mathrm{P} 2 \mathrm{X}_{7}$ channel) and other P2 purinoceptors such as $\mathrm{P} 2 \mathrm{Y}$ and $\mathrm{P} 2 \mathrm{U}$ (not shown) may be important at this stage. The final outcome of this process will depend on the relative intensity of each event. A dominance of the $\mathrm{Ca}^{2+}$-dependent $\mathrm{K}^{+}$channels will keep the cell in a hyperpolarized state and avoid membrane permeabilization. On the other hand, a dominance of $\mathrm{P} 2 \mathrm{X}_{7}$ currents will depolarize the cell and favor the opening of $\mathrm{Z}$ pores and membrane permeabilization.

The elucidation of the physiological role of extracellular ATP requires the study of the expression and activity of all receptors and channels involved in P2-dependent phenomena. The use of electrophysiological and other biophysical tools will continue to provide new clues for the understanding of the possible immunoregulatory role of these purinoceptors.

\section{Acknowledgments}

The authors wish to thank Dr. Octavio Aprigliano for all the help that has made possible the measurement of free intracellular $\mathrm{Ca}^{2+}$ concentration, and Vandir da Costa and Marília Barchi Severo for technical assistance. 


\section{References}

1. Burnstock G (1990). Purinergic mechanisms. Annals of the New York Academy of Sciences, 603: 1-18.

2. Gordon JL (1986). Extracellular ATP: effects, sources and fate. Biochemical Journal, 233: 309-319.

3. Dubyak GR \& El-Moatassim C (1993). Signal transduction via P2-purinergic receptors for extracellular ATP and other nucleotides. American Journal of Physiology 265: C577-C606.

4. Steinberg TH, Newman AS, Swanson JA \& Silverstein SC (1987). ATP4- permeabilizes the plasma membrane of mouse macrophages to fluorescent dyes. Journal of Biological Chemistry, 262: 8884-8888.

5. Wiley JS, Chen R \& Jamieson GP (1993). The ATP4- receptor-operated channel P2Z class of human lymphocytes allows $\mathrm{Ba}^{2+}$ and ethidium ${ }^{+}$uptake-inhibition of fluxes by suramin. Archives of Biochemistry and Biophysics, 305: 54-60.

6. El-Moatassim C, Bernad N, Mani J-C \& Dornand J (1989). Extracellular ATP induces a nonspecific permeability of thymocyte plasma membranes. Biochemistry and Cell Biology, 67: 495-502.

7. Nijweide PJ, Modderman WE \& Hagenaars CE (1995). Extracellular adenosine triphosphate: A shock to hemopoietic cells. Clinical Orthopaedics and Related Research, 313: 92-102.

8. Cockcroft S \& Gomperts BD (1980). The ATP4- receptor of rat mast cells. Biochemical Journal, 188: 789-798.

9. Coutinho-Silva R, Alves LA, Campos-deCarvalho AC, Savino W \& Persechini PM (1996). Characterization of $P_{2 z}$ purinergic receptors on phagocytic cells of the thymic reticulum in culture. Biochimica et Biophysica Acta, 1280: 217-222.

10. Zheng LM, Zychlinsky A, Liu C-C, Ojcius DM \& Young JD-E (1991). Extracellular ATP as a trigger for apoptosis or programmed cell death. Journal of Cell Biology, 112: 279-288.

11. Pfeilschifter J, Thuring B \& Festa F (1989). Extracellular ATP stimulates poly(inositol phospholipid) hydrolysis and eicosanoid synthesis in mouse peritoneal macrophages in culture. European Journal of Biochemistry, 186: 509-513.

12. Perregaux D \& Gabel CA (1994). Interleukin-1 1 maturation and release in response to ATP and nigericin. Journal of Biological Chemistry, 269: 15195-15203.
13. Tonetti $M$, Sturla L, Giovine $M$, Benatti $U$ \& Deflora A (1995). Extracellular ATP enhances mRNA levels of nitric oxide synthase and TNF-alpha in lipopolysaccharide-treated RAW 264.7 murine macrophages. Biochemical and Biophysical Research Communications, 214: 125-130.

14. Denlinger LC, Fisette $P L$, Garis KA, Kwon G, Vazqueztorres A, Simon AD, Nguyen B, Proctor RA, Bertics PJ \& Corbett JA (1996). Regulation of inducible nitric oxide synthase expression by macrophage purinoceptors and calcium. Journal of Biological Chemistry, 271: 337-342.

15. Nakanishi $M$, Takihara $H$, Minoru $Y$ \& Yagawa K (1991). Extracellular ATP itself elicits superoxide generation in guinea pig peritoneal macrophages. FEBS Letters, 282: 91-94.

16. Alexander SPH \& Peters JA (1997). Receptor and ion channel nomenclature supplement. Trends in Pharmacological Sciences, 18: 65-68.

17. Alonso-Torre SR \& Trautmann A (1993). Calcium responses elicited by nucleotides in macrophages - interaction between two receptor subtypes. Journal of Biological Chemistry, 268: 18640-18647.

18. Albuquerque C, Oliveira SM, CoutinhoSilva R, Oliveira-Castro GM \& Persechini PM (1993). ATP- and UTP-induced currents in macrophages and macrophagepolykaryons. American Journal of Physiology, 265: C1663-C1673.

19. Falzoni S, Munerati M, Ferrari D, Spisani S, Moretti S \& DiVirgilio F (1995). The purinergic $\mathrm{P} 2 \mathrm{Z}$ receptor of human macrophage cells - Characterization and possible physiological role. Journal of Clinical Investigation, 95: 1207-1216.

20. McMillian MK, Soltoff SP, Cantley LC \& Talamo BR (1987). Extracellular ATP elevates intracellular calcium in rat parotid acinar cells. Biochemical and Biophysical Research Communications, 149: 523-530.

21. Nuttle LC \& Dubyak GR (1994). Differential activation of cation channels and nonselective pores by macrophage P-2Z purinergic receptors expressed in Xenopus oocytes. Journal of Biological Chemistry, 269: 13988-13996.

22. Blanchard DK, Hoffman SL \& Djeu JY (1995). Inhibition of extracellular ATP-mediated lysis of human macrophages by calmodulin antagonists. Journal of Cellular Biochemistry, 57: 452-464.
23. DiVirgilio F (1995). The P2Z purinoceptor: an intriguing role in immunity, inflammation and cell death. Immunology Today, 16: 524-528.

24. Laliberte R, Perregaux D, Svensson L, Pazoles CJ \& Gabel CA (1994). Tenidap modulates cytoplasmic $\mathrm{pH}$ and inhibits anion transport in vitro. 2. Inhibition of IL-1 beta production from ATP-treated monocytes and macrophages. Journal of Immunology, 153: 2168-2179.

25. Molloy A, Meyn PA, Smith KD \& Kaplan G (1993). Recognition and destruction of bacillus Calmette-Guérin-infected human monocytes. Journal of ExperimentalMedicine, 177: 1691-1698.

26. Jamieson GP, Snook MB, Thurlow PJ \& Wiley JS (1996). Extracellular ATP causes loss of L-selectin from human lymphocytes via occupancy of P2Z purinoceptors. Journal of Cellular Physiology, 166: 637-642.

27. Chen ZP, Levy A \& Lightman SL (1995). Nucleotides as extracellular signalling molecules. Journal of Neuroendocrinology, 7: 83-96.

28. Alonso-Torre SR \& Trautmann A (1995). Rapid refilling of $\mathrm{Ca}^{2+}$ stores in macrophages stimulated by ATP involves the sequential activation of phospholipase $D$ and protein kinase C. Pflügers Archiv. European Journal of Physiology, 430: 230237.

29. Naumov AP, Kiselyov KI, Mamin AG, Kaznacheyeva EV, Kuryshev YA \& Mozhayeva GN (1995). ATP-operated calcium-permeable channels activated via a guanine nucleotide-dependent mechanism in rat macrophages. Journal of Physiology, 486: 339-347.

30. Humphreys BD \& Dubyak GR (1996). Induction of the $\mathrm{P} 2 \mathrm{Z} / \mathrm{P} 2 \mathrm{X}_{7}$ nucleotide receptor and associated phospholipase $D$ activity by lipopolysaccharide and IFNgamma in the human THP-1 monocytic cell line. Journal of Immunology, 157: 5627-5637.

31. Gargett CE, Cornish EJ \& Wiley JS (1996). Phospholipase D activation by P-2Zpurinoceptor agonists in human lymphocytes is dependent on bivalent cation influx. Biochemical Journal, 313: 529-535.

32. Surprenant $A$, Rassendren F, Kawashima E, North RA \& Buell G (1996). The cytolytic $\mathrm{P}_{2 Z}$ receptor for extracellular ATP identified as a $P_{2 X}$ receptor $\left(P_{2} X_{7}\right)$. Science, 272: 735-738. 
33. Tatham PER \& Lindau M (1990). ATP-induced pore formation in the plasma membrane of rat peritoneal mast cells. Journal of General Physiology, 95: 459-476.

34. Hara $N$, Ichinose $M$, Sawada $M$, Imai $K$ \& Maeno $T$ (1990). Activation of single $\mathrm{Ca}^{2+}$ dependent $\mathrm{K}^{+}$channel by external ATP in mouse macrophages. FEBS Letters, 2: 281-284.

35. Bretschneider F, Klapperstuck M, Lohn M \& Markwardt F (1995). Nonselective cationic currents elicited by extracellular ATP in human and B-lymphocytes. Pflügers Archiv. European Journal of Physiology, 429: 691-698.
36. Coutinho-Silva R, Alves LA, Savino W \& Persechini PM (1996). A cation non-selective channel induced by extracellular ATP in macrophages and phagocytic cells of thymic reticulum. Biochimica et Biophysica Acta, 1278: 125-130.

37. Alves LA, Coutinho-Silva $R$, Persechini PM, Spray DC, Savino W \& Campos-deCarvalho AC (1996). Are there functional gap junctions or junctional hemichannels in macrophages? Blood, 88: 328-334.

38. Persechini PM, Coutinho-Silva R, Alves LA, Campos de Carvalho AC \& Savino W (1996). The P2Z purinoceptor: an open question in the immune system. Immunology Today, 17: 292-293.
39. Buisman HP, Steinberg TH, Fischbarg J Silverstein SC, Vogelzang SA, Ince C, Ypey DL \& Leijh PCJ (1988). Extracellular ATP induces a large nonselective conductance in macrophage plasma membranes. Proceedings of the National Academy of Sciences, USA, 85: 7988-7992.

40. Coutinho-Silva R \& Persechini PM (1997) P2Z purinoceptor-associated pores induced by extracellular ATP in macrophages and J774 cells. American Journal of Physiology, 273: (in press).

41. Beyer EC \& Steinberg TH (1991). Evidence that the gap junction protein connexin-43 is the ATP-induced pore of mouse macrophages. Journal of Biological Chemistry, 266: 7971-7974. 